\title{
Institutional Strategies for the Teacher Training at a Brazilian Public University in Brazil—Elements of Reflection
}

\author{
Adriana K. Corrêa ${ }^{1}$, Alma B. C. E. B. Catirse ${ }^{2}$, Edson G. Soares ${ }^{3}$, Glaucia M. Silva ${ }^{4}$, \\ Maria Conceição B. M. e Souza ${ }^{5}$, Marlene F. C. Gonçalves ${ }^{5}$, Noeli Prestes Padilha Rivas ${ }^{6} \&$ Yassuko Iamamoto $^{4}$ \\ ${ }^{1}$ Departamento de Enfermagem Geral e Especializada, Escola de Enfermagem de Ribeirão Preto, Universidade \\ de São Paulo, Ribeirão Preto, São Paulo, Brazil \\ ${ }^{2}$ Departamento de Materiais Dentários e Prótese, Faculdade de Odontologia de Ribeirão Preto, Universidade de \\ São Paulo, Ribeirão Preto, São Paulo, Brazil \\ ${ }^{3}$ Departamento de Patologia e Medicina Legal, Faculdade de Medicina de Ribeirão Preto, Universidade de São \\ Paulo, Ribeirão Preto, São Paulo, Brazil \\ ${ }^{4}$ Departamento de Química, Faculdade de Filosofia, Ciências e Letras de Ribeirão Preto, Universidade de São \\ Paulo, Ribeirão Preto, Brazil \\ ${ }^{5}$ Departamento de Enfermagem Psiquiátrica e Ciências Humanas, Escola de Enfermagem de Ribeirão Preto, \\ Universidade de São Paulo, Ribeirão Preto, São Paulo, Brazil \\ ${ }^{6}$ Departamento de Educação, Informação e Comunicação, Faculdade de Filosofia, Ciências e Letras de Ribeirão \\ Preto, Universidade de São Paulo, Ribeirão Preto, Brazil \\ Correspondence: Adriana K. Corrêa, Escola de Enfermagem de Ribeirão Preto, Universidade de São Paulo, \\ Ribeirão Preto, SP, 14040902, Brazil. Tel: 55-16-3315-3436. E-mail: adricor@eerp.usp.br
}

Received: September 7, 2016

doi:10.5539/ies.v10n3p1

\author{
Accepted: October 11, $2016 \quad$ Online Published: February 27, 2017 \\ URL: https://doi.org/10.5539/ies.v10n3p1
}

\begin{abstract}
University pedagogy has been promoted in the context of the policy for valuing undergraduate training at the University of São Paulo (USP). In this regard, one action of the Undergraduate Pro-Rectory was the creation of pedagogic support groups. The objective of this study is to report and analyze the strategies for university teacher training developed by the Pedagogic Support Group at the Ribeirão Preto Campus (GAPRP/USP-Grupo de Apoio Pedagógico do Campus de Ribeirão Preto), during the period from 2002 to 2015. The group takes on a conception of teacher training that extrapolates the technical dimension, considering political-social and historical determinants that have shaped the university, undergraduate teaching, and the faculty, as well as the valorization of strategies promoting reflection, theoretical-practical articulation, and collective learning. During the day-to-day monitoring of these education strategies, a few aspects are highlighted and analyzed: identification of the need for pedagogic training as an individual initiative of the teaching staff, despite the policies for valuing undergraduate training; investment in continuous educational strategies and the education undergone by the faculty that compose GAPRP/USP. To conclude, teacher training means to value the construction of a political project so as to qualify university teachers.
\end{abstract}

Keywords: higher education, pedagogic support group, professional development of teachers, teacher training, university pedagogy

\section{Introduction}

University pedagogy has been promoted in the context of the policy for valuing undergraduate training at the University of São Paulo (USP), in Brazil. One of the actions taken by the Undergraduate Pro-Rectory was the creation of pedagogic support groups (GAPs - Grupos de Apoio Pedagógico), composed of teachers working at the university itself, from different fields of knowledge, interested in university pedagogy and committed to the proposition and development of educational actions for university teachers.

The University of São Paulo consists of campi located in various municipalities in the state of São Paulo, namely: Bauru, Lorena, São Paulo, Piracicaba, Pirassununga, Ribeirão Preto, and São Carlos. The first pedagogic support group to be created at the University of São Paulo was the Pedagogic Support Group of the Ribeirão Preto 
Campus (GAPRP/USP), which began its activities in September 2002, even before the university took on the creation of groups of this kind as a formal strategy.

In 2004, through the Undergraduate Pro-Rectory's Internal Ordinance nº 04/2004 (Universidade de São Paulo, 2004) which discusses the main pedagogic support actions for teachers at the University of São Paulo, the proposal for creating GAPs at USP was formalized. In this context, GAPRP/USP continues the activities that it had already begun executing. The ordinance indicates the need to value undergraduate activities and to construct spaces for improvement of the teachers, considering the pedagogic practice and support to the teacher in fulfilling the propositions regarding the objectives and the National Undergraduate Guidelines.

The main objective of GAPRP/USP is to contribute to the pedagogic improvement of the teaching staff to fulfill the National Undergraduate Guidelines, supporting the Faculty Undergraduate Committees, Coordination Committees of the specific undergraduate program, and teaching staff, so that they can renew and improve their knowledge with the purpose of promoting necessary changes in the pedagogic practice. At the University of São Paulo, management of undergraduate teaching is performed through the abovementioned committees.

The specific objectives of the group are: promoting innovative pedagogic practices in undergraduate courses, based on university pedagogy courses, continuous studies, seminars, and workshops on pedagogical knowledge, considering the shared needs of the faculties; encouraging and developing studies on topics related to university pedagogy, involving different faculties; supporting the exchange of pedagogical experiences among the teachers regarding curricular changes, construction/implementation of political-pedagogic projects, innovations to teaching methods, and assessment practices, among others.

At the start of its activities, GAPRP/USP prioritized the organization of events aimed at the field of knowledge of university pedagogy, characterized by seminars, conferences, and round-table discussions. The intention was to promote large encounters gathering teachers from the Ribeirão Preto USP campus, inciting motivation for the group's work and identifying educational requirements of the teachers themselves. It is worth noting that from 2003 to 2015 a number of events were held with focal themes regarding: political-pedagogic project, evaluation of higher education, new demands for pedagogic education of university teachers, and interdisciplinarity of teaching, among others.

As a suggestion by the teachers who participated in these meetings, study groups were organized regarding interdisciplinarity, assessment of the learning-teaching process, psychosocial aspects of the undergraduates, and distance learning that were held until 2004, given the difficulties of the teachers in maintaining effective participation due to the multiple activities, competing priorities placed on the teaching career.

Next, "open meetings" were organized-study meetings held once a month, coordinated by the members of GAPRP/USP and open to the community of teachers and graduate students. This model of educational experience arose when GAPRP/USP members involved with research on the pedagogic practice of university teachers selected specific texts of university pedagogy to study-with the view that learning could be shared with other interested teachers. Thus, from 2007 until now, on a monthly or bimonthly basis, one of the teachers of the group coordinates the meeting, presenting the main ideas of the text selected and stimulating discussions and reflections. There have been a limited number of participants, considering the number of campus teachers, also including some graduate students. However, despite this, the discussions are always enriching, since they promote new understanding of important topics in the pedagogic practice, and also provide an opportunity for theoretical-practical articulation and the shared search for daily strategic actions that value undergraduate training.

Throughout the years, feeling more structured as a group recognized by the faculty, GAPRP/USP began to notice that it would be extremely important to invest in more continuous educational actions that make it possible for teachers to gradually construct knowledge. Thus, in 2008 and 2009, with support from the Undergraduate Pro-Rectory, the board of directors of the teaching units at the USP-Ribeirão Preto campus, and the coordination and organization of GAPRP/USP, two "Inland University Pedagogy Courses" were administered by a teacher specialized in the field of university pedagogy. The first had 100 hours and 71 participants, and the second, 260 hours and 73 participating teachers. In 2011, another "University Pedagogy" course was administered in partnership with the university's School of Education, with a course load of 240 hours and 30 participants. In 2015, another "University Pedagogy" course was held - coordinated, organized, and administered by teachers of GAPRP/USP, with 120 hours and 37 participating teachers.

Although more continuous courses were prioritized, GAPRP/USP still organized more sporadic events that also have proven to be important for raising awareness of teachers regarding the challenges of university teaching, grouping a significant number of teachers concerned with teaching as a profession and with the need for specific 
and permanent education. In addition, such events also provide visibility to the group that, recognized by the teachers of the campus community, acquires more confidence to maintain and consolidate more continuous actions of pedagogic education.

It should be noted that GAPRP/USP uses a conception of teacher training that extrapolates the technical dimension (Severino, 2002; Pimenta \& Anastasiou, 2014), in other words, it considers political-social and historical determinants that affect the university, undergraduate training, and the faculty as key elements that are always present in the decisions that involve the curriculum, education program, assessment practices, student relations, and course management, among others.

In this context, the objective of this reflexive study is to describe and analyze the educational strategies for university teachers developed by GAPRP/USP during the period from 2002 to 2015.

The analysis was based on the coordination, development, and daily monitoring of these strategies by the teachers who composed the group, grounded in the work of authors of the field of knowledge of university pedagogy: "a scientific field in a phase of legitimization that articulates the dimensions of teaching and research in the places and spaces of education" (Cunha, 2010). This field considers theories and practices for the teachers training, assuming the institutional responsibility for the pedagogical processes undertaken in the academic environment.

\section{Strategies for the University Teachers Training: Reflections of GAPRP/USP}

Though the coordination, execution, and daily monitoring of the education strategies proposed by GAPRP/USP, some dimensions are highlighted for analysis: recognition of the need for pedagogic training as a predominantly individual initiative of the teachers; investment in educational strategies that are continuous and based on critical, reflexive references and their implications; and the peculiar opportunity of pedagogic training experienced by the teachers that are part of GAPRP/USP. Below are some considerations on these dimensions.

\subsection{Recognition of the Need for Pedagogic Training as a Predominantly Individual Initiative of the Teachers}

Both in the sporadic meetings and in the continuous courses, the recognition of the need for pedagogic training appears mainly as an individual initiative of the teachers. Despite the policies for valuing undergraduate training, at the university, the logic predominates that teachers are valued mainly through their involvement and prominence in research (Cunha, 2014), which makes it difficult for the teachers to effectively engage in the education activities related to undergraduate teaching, given that they end up being considered more poorly in the assessment processes that involve professional progression.

In this light, valuing the pedagogic training of university teachers is challenging because the education of university faculty, unlike other levels of teaching, was historically established based on the specialty that the teacher thus far exercises in the work environment. In other words, the idea that "whoever can do it can teach it" is the dominant logic. In addition, the university teaching community is based significantly on the epistemological concept of modern science that much more greatly legitimizes specific content to the detriment of pedagogic and humanities knowledge in the training of teachers. Aligned with these aspects, it is valid to consider that the concept of teaching as a gift also regards pedagogic knowledge as a background element (Cunha, 2006).

Thus, at the university, teacher training is almost always restricted to scientific education in the area of specific knowledge transmitted through masters and doctorate courses, which reveals that to be a university teacher it suffices to have knowledge of the specialty and academic forms of producing it (Cunha, 2014). In addition, it is valid to consider that this teacher training is also legally legitimated, since the Law of Directives and Bases of National Education (LDB 9394/96), in its article 66, indicates that "preparation for the exercise of university teaching will be done on a graduate level, primarily in masters and doctorate programs" (Brazil, 1996).

Regarding the identity of the teacher in higher education, some abovementioned problems can be highlighted: researchers begin teaching without opportunities for questioning the meaning of being a teacher; in the masters and doctorate courses, there are few moments for further development in teaching. In addition, the authors point out that the teachers do not research their own teaching (Pimenta \& Anastasiou, 2014).

The problem of university teacher training seems to become even more significant in the current configuration, considering the university-neoliberal state relations and their implications for the professionality of the teachers.

While the university adheres non-critically to the "objectives" of society, currently more identified with technocratic and managerial orientation, the university ends up abdicating its function of education and empowerment of the subjects. With the expansion of the market economy, higher education was led to limit its 
capacity for criticism, autonomy of thought, and comprehensive understanding of human history (Sobrinho, 2005).

Mainstream thinking expects that higher education is more focused on economic function and labor skills, with mainly shortsighted, pragmatic, and individualistic demands: "the neoliberal orthodoxy and its practices lead universities to abandon, at least partly, their traditional vocation of knowledge construction and education as public goods, adopting the market - and not society - as their central reference." In this regard, higher education is important for disseminating knowledge, as well as the capacity for using the knowledge acquired, and continuous learning. These elements maintain the competitiveness of the individuals, companies, and countries developed. In this light, "the idea sold as true is that of a world knowledge fed by the determinism of technology as the motor and equalizer of progress, and of a religious belief in the global market to replace national inequalities and eclipse injustices in the access to and use of knowledge. Instantaneous and worldwide communication would provide greater human cohesion. The fundamentalist and one-dimensional view of the market, anointed by technology and its power of potentiating information, hides the real situation of the fraying of human relations, the fading of public order, and the atomization of subjective experiences" (Sobrinho, 2005).

Despite the current policy of valuing undergraduate teaching, in the day-to-day micro level, the interest and the recognition of the teacher participation importance in educational spaces have proven to be an individual initiative. If, on the one hand, this individual initiative can hinder the construction of day-to-day changes in undergraduate training by the teachers, since they also involve institutional decisions (Zabalza, 2004), on the other hand, the teachers who engage in the strategies offered are almost always genuinely mobilized to rethink their practice. Even with this engagement, for some teachers, it is difficult to participate in continuous activities, given the various other institutional demands placed on them. This shows that the creation of spaces for reflection and construction of knowledge on the pedagogic teaching practice is a great challenge, a contradiction for the university, whose primary function is to educate people.

At the same time, participation in these spaces allows teachers to identify with one another regarding the problems, values, and projects related to undergraduate training. This identification empowers them to engage in these activities, as well as defend undergraduate training vis-a-vis their faculties. In other words, the individualistic character of the initial participation of the teacher becomes part of a collective project.

In this regard, university teachers, in their day-to-day activities, have a professional practice more characterized by the execution of individual activities, with little exercise of collective work. The spaces for more effective discussion regarding the pedagogic practice and the meanings of education are few. It is worth highlighting that the current LDB demands that each course be constructed based on a collectively elaborated political pedagogic project.

This proposal requires that the teachers organize themselves in a course collegiate, discussing and making collective decisions on teaching. However, these results in the emergence of resistance, given the political context described above, as well as interpersonal difficulties.

Despite the external legal determinations and the policy of valuing undergraduate training at the university, support for participation in activities for teacher training and, mainly, their recognition as an important element in academic life, inclusive in the processes of teacher evaluation, are still incipient. When they do occur-as experience has demonstrated us-they did not necessarily generate the conditions for comprehensive transformations in teaching practices, as these involve other dimensions, such as the institutional support.

The main instance responsible for education is the administration of the universities, who have the responsibility of outlining the guidelines of the educational policy, establishing priorities and guaranteeing the necessary resources (Zabalza, 2004).

In a dialectic relationship between individual and collective dimensions, some teachers may introduce more immediate modifications in their activities (such as, for example, in the way they manage the classroom, in the use of innovative teaching strategies), as well as instigate their colleagues to exchange knowledge and questions regarding the pedagogic practice, which has been reported by the teachers who participate in the university pedagogy courses offered by GAPRP/USP.

This could be more effective if it were possible the participation in the university pedagogy courses of a significant number of teachers who work together in the same undergraduate program and who were willing to change their practice (Anastasiou, 2004). However, in these courses it has not been possible to adopt this methodology. In general, the teachers who participate are from different undergraduate programs and, when from the same programs, are not necessarily representative of different knowledge areas that compose the curriculum, 
which hinders the transformative potential. In any case, even the more effective participation of teachers from the same program would not generate changes in undergraduate training without institutional support.

It is important to highlight that the possibility of establishing oneself as a teacher, inserting oneself in an educational project, mainly in the courses of university pedagogy that are more continuous and which value the collective space, has proven to be very promising, as it opens the space so that other forms of educational exercise can at least be discussed beyond the more individualized work that is already known.

Resuming the predomination of the teachers' individual initiative regarding the recognition of the need for pedagogic training-an idea which generated the presentation, in this text, of some of the problems that currently occur in the teacher training at universities-, it can be understood that the policy for valuing undergraduate training faces other policies that do not necessarily coincide with encouraging teacher training, mainly in the critical-reflexive perspective.

\subsection{Investment in Continuous Educational Strategies Based on Critical-Reflexive References and Its Implications}

Another fundamental dimension to be analyzed is: GAPRP/USP, over the last few years, has invested in more continuous educational strategies that allow the development of critical educational practices (Anastasiou, 2004), considering the concept of teaching training undertaken by the group.

Since the beginning of their work, the teachers who compose GAPRP/USP have shared the idea that their role is to create spaces for reflection that build theoretical groundwork to serve as a foundation for the critical interpretation of the university teaching, strengthening the transformative perspective, which involves to transcend the technical dimension of educational practices. This idea has been gradually constructed in the university pedagogy courses initiated in 2008. One of the fundamental elements stated at the beginning of these courses is that the aim is not to teach how to "lecture", sharing the need, but to comprehend the university teaching in their historical-social construction that which is also related to the understanding of the teaching in its dimension of professionality.

Regarding the teacher, the idea of professionality can be more adequate than that of a profession, since the teaching practice is not static and permanent, but processual (Cunha, 2007). This idea goes against the historical premise of the teacher's job: a teaching activity grounded in a body of knowledge that is scientifically and culturally legitimized, for which reason erudition is considered a highly valued practice, since the teacher is seen as the keeper of this body of knowledge. In this perspective, the founding element of teaching consists of the organization of the content to be taught, considering its parts and prerequisites, without significant preoccupation with the learning subjects and the context in which the learning occurs.

Thus, emphasizing teaching as a process in construction involves valuing the professional development of the faculty. This development values an education no longer based on technical rationality, which considers teachers mere executors of the decisions of others, but in a focus that recognizes their decision-making capacity. When confronting their daily actions with the theoretical productions, it is possible to review their practices and the theories on which they are based, "researching the practice and producing new knowledge for the theory and practice of teaching". Thus, the transformations of the teaching practices only materialize as long as the teachers expand their awareness regarding their own practices, including the classroom and the university, which involves theoretical and critical knowledge regarding reality (Pimenta, 2009).

The concept of development involves the evolution and continuity between the initial education and that which is continued. Professional development "is characterized by a permanent attitude of investigation and planning questions and problems and the search for their solutions", assuming an approach in education that values its contextual, organizational, and change-oriented aspects. Professional development entails concrete collaborative tasks of teaching, assessing, observing, and reflecting, throughout a long-term process in different contexts (Marcelo \& Vaillant, 2009).

In this perspective, the practice of teaching is complex - a professional activity that demands the condition of knowing how to justify what is done, with arguments grounded in conceptual bases, diverging from the amateur practice of the profession, which tends to maintain culturally solidified processes reproduced in daily life (Cunha, 2007).

It is also relevant to note that, regarding university teaching, there is limited or basically no pedagogic training, making it urgently necessary to invest in the practices of continuous education from a critical perspective.

For many teachers, contact with the theoretical bases in which the teaching practice is grounded differs greatly from the contact they have with their specific fields of knowledge. Thus, in the university pedagogy courses, topics and teaching strategies that follow this perspective have been chosen: the historical context of the 
university; the political and legal determinants that serve as a foundation for undergraduate training; and contents that relate the pedagogic practice to specific notions regarding humankind, the world, and the society. This understanding of the pedagogic process is particularly important, since it considers its historical context and its articulation of disciplinary knowledge, challenging its boundaries.

It is not possible to state that these topics were significantly learned by the participants, despite the fact that some processual evaluations during the university pedagogy course have indicated so. In a study (Pachane, 2005) that analyzed an "internship and teacher training program" from another Brazilian public university, directed toward graduate students, it was found that the social-political dimension (related to the comprehensive understanding of education, involving comprehension of the social and educational policies) was at least mentioned in the reports of the students.

The tendency for teachers to withdraw somewhat from more comprehensive topics related to the political-social context in which their work is inserted justifies the focus of the abovementioned topics.

In addition, in the university pedagogy courses thus far administered, the experience of teachers are valued as triggers for learning and theoretical-practical articulation, not only for promoting technical instrumentation that meets their immediate aspirations, but also education that also involves political, organizational, and relational elements present in everyday practices. Another important aspect that has been encouraged in university pedagogy courses is the execution of collective activities within and outside the classroom that provide the challenging exercise of producing diversity.

In this context, it must be recognized that the professional capacity of the teacher is not reduced to technical and disciplinary education, but requires pedagogical practice and theory that ground the teaching activity. Thus, permanent education should foster more reflection of the subjects regarding their teaching practice, uncovering implicit premises, frames and attitudes. This can favor the construction of a daily process of self-evaluation, related to what is done and why it is done. Educational orientation that can sustain this reflexive process requires a critical proposal of the organization and of the methodology of the educational actions by the teachers, providing conditions for those involved to rethink assumptions of ideology and attitude that structure their practices (Imbernón, 2009).

Aside from the reflexive aspect, the perspective of continuous education, as opposed to the model of occasional training, is also understood in the literature as an important educational strategy. One of the fundamental elements of teacher professionalization is time. Professionalization is not restricted to the informative process, which can be developed, for example, in a seminar held over a few hours. While we accept the validity of such a strategy, preparation of a teacher involves the establishment of goals and continuous assessment over the course of an established period. Thus, sufficient time is necessary for the problems diagnosed to be faced and transformed into goals (Anastasiou, 2004).

The expression "continuous professionalization" carries within itself the movement necessary for continuous education, which is fundamental to teaching, considering the permanent involvement with beings that change and with knowledge that is constantly altered. In addition, continuous education implies unpredictability, singularity, uncertainty, innovation, dilemma, conflict, and instability, demanding from the teacher mental flexibility as an essential element (Anastasiou, 2004)

Thus, investing in continuous and reflexive educational practices is fundamental and has proven to be necessary in the current context, considering the demands of undergraduate training in Brazil. The current national undergraduate policies (Brazil, 1996; Brazil, 1997: Brazil, 1999; Brazil, 2014) indicate, among other aspects, encouragement for independent study practices and for activities that stimulate the investigation and construction of the critical capacity of the student, promoting professional and intellectual autonomy, integral education, fulfillment of social demands, and strengthening of theoretical-practical articulation and interdisciplinarity.

We highlight three pedagogic tendencies related to higher education. The first encompasses the existence of courses based on competence that educate students in the acquisition of professional skills that allow them to be well-prepared for the labour market. In this regard, the undergraduate and graduate courses encourage the development of high-level abilities, such as problem solving, metacognition, and social skills such as teamwork and communication abilities, so as to facilitate adaptation and mobility of students to develop their learning abilities over the course of their lives. This tendency is consolidated in North America and underway in Europe, since, according to the European University Association (EUA), undergraduate programs must prepare students for the job market, whose professional role would be in directing the job search and career management, which is also found in Brazil (Bédard, 2009). 
The second tendency reconfigures the system for recognizing the quality of education at universities, distinguishing the place and quality of the act of teaching. Progressively, universities offer pedagogic training to graduate students interested in a teaching career, and the members of the faculty have more and more access to courses or similar programs. In North America, a growing movement of publications related to teaching can be observed (Bédard, 2009). In Brazil, universities offer pedagogic preparation programs to graduates as a legal requirement of the Coordination for the Improvement of Higher Education Personnel (CAPES - Coordenação de Aperfeiçoamento de Pessoal de Nível Superior). In addition, associations of studies on teaching in various areas of knowledge have emerged, especially after the establishment of the national curricular guidelines for undergraduate courses by the Ministry of Education.

The third tendency emphasizes courses centered in the learning process, including those with diversified strategies for teaching methods, such as the dialectic method, learning through problems, case studies, approach per project, and group assignments, among others (Bédard, 2009). Given the academic culture that uses lectures as a main instrument in the learning process, there is resistance from teachers and students that hinders pedagogic innovation. In this regard, it can be argued that the more teaching considers the contexts in which the knowledge will be used, the more the students will be apt to act in diversified complex situations, considered "junction points between the professional ecosystem and academic ecosystem" (Bédard, 2009).

It is necessary to create a new academic culture that considers the following: "The right of access to education that guarantees students the development of a stance regarding knowledge, that overcomes narrow specialization, problematizes information, and guarantees their education as a citizen and professional scientist committed to the application of knowledge in favor of the improvement of the quality of life of all of society; that enables the development of autonomous thinking, substituting the mere transmission of knowledge for the engagement of the students; for a process that allows the student to interrogate the knowledge elaborated, to think and think critically; that gives rise to problem solving, stimulates discussion, develops research methodologies and those for the construction of knowledge (teaching with research); that confronts the knowledge elaborated and the research with reality; and that mobilizes inter and transdisciplinary views regarding the phenomena and points out and enables the solution of social problems (teaching with extension). A new academic culture that values the work of undergraduate teachers" (Almeida \& Pimenta, 2009).

It can be stated that this new academic culture leads to the reconfiguration of pedagogic practices, presenting a challenge that involves, among other aspects, the education of teachers in a critical-reflexive and continuous perspective.

\subsection{Pedagogic Training Experienced by the Teachers Who Compose GAPRP/USP}

To conclude, the last dimension to be considered is that the teachers who compose GAPRP/USP are nurtured by their participation in the planning, execution, and evaluation of these proposed educational strategies. Investing in the education of the educators is also education of oneself, with the other, in favor of a political project for qualifying faculty in university education.

The teachers who compose GAPRP/USP, from the beginning of their activities, have discussed the pedagogic education of university teachers, planning, monitoring, and evaluating teacher training actions, from the occasional training to the more continuous university pedagogy courses, and dedicating themselves to the development of research in the field of knowledge of university pedagogy. In addition, the group maintains an important partnership with the Teaching Units at the USP Ribeirão Preto Campus, in the sense of maintaining and consolidating their acting space together with the community, which entails a permanent search for political-institutional support for the group's work.

Thus, the teachers, in their weekly meetings, have opportunities to reflect on their pedagogic practice, debating their role as teacher in the context of USP, pointing out problems they have in common and constructing individual and collective strategies for facing them. Organizing and participating in events are also interesting moments for reviewing and learning knowledge, as well as, mainly, renovation of enthusiasm in maintaining commitment to the objectives of the group, since these events are also opportunities for exchanging experiences with other teaching colleagues and sharing common concerns and projects.

Insertion in the organization of and participation in university pedagogic courses, in turn, has been an uneven opportunity, since, while the faculty of GAPRP/USP, until a certain point, have also been students of these courses, they have taken on the arduous task of generating the structural conditions and monitoring the pedagogic process. The reading of texts, the undertaking of tasks that sought to articulate theory and practice, participation in discussions, and at some moments, the coordination and execution of specific activities alongside the group of "student-teachers" of the course allowed theoretical references to be learned that grounded the 
comprehension of the reality and the proposition of new actions.

In this regard, the activity of GAPRP/USP members has significant continuous and critical-reflexive educational aspects. In processes of continuous education, the teachers learn based on the analysis and interpretation of their own pedagogic activity. Through seminars and individual and collective assignments, the role of the teacher in university education can be re-thought, and this reflection only makes sense when it emerges from the teaching action as a day-to-day practice (Cortelletti, Ribeiro, \& Stedille, 2002).

The search for a pedagogic practice that improves the quality of the teaching-learning process and of paths that lead to the construction of knowledge that surpasses the arrogance of crystalized knowledge is a challenge in higher education. Knowledge originates from an observer/observable object relationship and observation process, where the individual is an active participant of the construction of knowledge, also using sensations, feelings, emotions, and intuition to learn (Cortelletti, Ribeiro, \& Stedille, 2002).

It is important to explicitly highlight the singular experience of the teachers who compose GAPRP/USP, constructing themselves as subjects that dialogue between theory and practice, reconstructing themselves in this continuous educational path. Thus, this is a perspective of continuous education that differs from the traditional one - in other words, from that which is summarized in a moment of "updating" the teachers, based on training and instruction actions insufficient to transform the classroom and the educational institution. This traditional perspective has proven, historically, to be inadequate, since the teacher is placed in the position of a subject who repeats theories, techniques, and practices, thought of by other professionals, generally specialists and academics considered to be unquestionable references (Imbernón, 2010).

The configuration of GAPRP/USP is similar to the team model, since teachers from various fields of knowledge are present, from all faculties of the campus, belonging to biological, exact, and human sciences, which has favored the recognition of the group along with the teaching community, avoiding the creation of stereotyped views that could restrict the necessity for pedagogic education to only a few professional areas. Based on the encounter between educators from different areas, spaces for socialization and learning of new knowledge of the pedagogic field can be generated, many times differing from the original field of knowledge of the teachers.

The group comprehends, in their role as "educators of educators", that they will be better enabled to approach their teacher colleagues as they take on the condition of subjects of their own education, opening up to the sharing of experiences and knowledge, in the production of a collective work, constructed based on singularity and diversity. Thus, this is the construction of a collective work attitude that is highly necessary for the day-to-day practices that also involve the personal dimension of the teacher.

Education is not constructed through accumulation, be it of courses, knowledge, or techniques, but through a work of critical reflection on the practices and permanent reconstruction of personal identity (Nóvoa, 1997). In this regard, the educators from GAPRP/USP are involved in the teacher training project, and the genesis of this involvement arises from their commitment to their own education, however, understood not only as an individual informative activity, but as a collective, educational, emancipating process. The personal dimension is also involved, since proposing to undertake the reflection of their pedagogic practice along with other teachers involves an attitude of removal from a comfortable situation to allow themselves to be questioned and provoked, overcoming resistances common to innovations.

The performance of studies regarding the pedagogic practice of teachers at the USP Ribeirão Preto Campus has been one of the most important elements in the process of educating the educators. The primary intention of the group is that the results of these studies may guide the proposals of educational activities for the faculty at the USP/RP campus.

\section{Final Considerations}

The analysis of the strategies for university teacher training, organized and monitored by the group of teachers that compose GAPRP/USP, allows us to learn some significant elements such as: the dominance of the individual initiative of teachers regarding the recognition of the need for pedagogic education, despite the institutional policies valuing undergraduate teaching; and the potential of the continuous educational actions with critical-reflexive focus, given the possibility of analysis and transformation of the reality and opportunity of training experienced by the teachers involved in such strategies, to the extent that they are involved in their own education, allowing collective spaces for teacher training.

Such strategies can solidify teachers' commitment to transforming their day-to-day practice, fostering the construction of new methods of teaching and learning and of managing undergraduate education. 


\section{Acknowledgments}

This study was supported by the Pro-Health Education Project (2037/2010), the Coordination for Improvement of Higher Education Personnel and the Undergraduate Pro-Rectory at USP (2003 to 2014).

\section{References}

Almeida; M. I., \& Pimenta, S. G. (2009). Pedagogia Universitária: valorizando o ensino e a docência na Universidade de São Paulo. In S. G. Pimenta, \& M. I. Almeida (Eds.), Pedagogia Universitária (pp. 13-38). São Paulo, Brazil: EDUSP.

Anastasiou, L. G. C. (2004). Profissionalização continuada: aproximações da teoria e da prática. In R. L. L. Barbosa (Ed.), Trajetórias e perspectivas da formação de educadores (pp. 9-22). São Paulo, Brazil: UNESP.

Bédard, D. (2009). Ensino universitário, profissionalização: perspectivas pedagógicas. In M. I. Cunha, S. R. Soares, \& M. L. Ribeiro (Eds.), Docência universitária: profissionalização e práticas educativas (pp. 133-150). Feira de Santana, Brazil: UEFS.

Brazil (1996). Lei no. 9.394/96: Estabelece as Diretrizes e Bases da Educação Nacional. Brasília, Brazil: Diário Oficial da União, 27834-27841. $\quad$ Retrieved http://pesquisa.in.gov.br/imprensa/jsp/visualiza/index.jsp?jornal=1\&pagina=1\&data=23/12/1996

Brazil (1997). Parecer no 776/97: Orientação para as diretrizes curriculares dos cursos de graduação. Brasília, Brazil: Ministério da Educação. Retrieved from http://portal.mec.gov.br/cne/arquivos/pdf/CES0776.pdf

Brazil (1999). Plano Nacional de Graduação: um projeto em construção. Brasília, Brazil: Fórum de $\begin{array}{lllll}\text { Pró-Reitores das } & \text { Universidades } & \text { Brasileiras. } & \text { Retrieved }\end{array}$ http://portal.mec.gov.br/sesu/arquivos/pdf/png.pdf

Brazil (2014). Lei $n^{\circ}$ 13.005/14: Aprova o Plano Nacional de Educação (2014-2024). Diário Oficial da União, 120(A), 1-7. Retrieved from http://pesquisa.in.gov.br/imprensa/jsp/ visualiza/index.jsp?Jornal=1000\& pagina $=1 \&$ data $=26 / 06 / 2014$

Cortelletti, I. A., Ribeiro, L. B. M., \& Stedille, N. L. R (2002). Reflexão sobre a ação: uma estratégia de formação de professores em nivel superior de ensino. Caxias do Sul, Brazil: EDUCS.

Cunha, M. I. (2006). A universidade: desafios políticos e epistemológicos. In M. I. Cunha (Ed.), Pedagogia universitária: energias emancipatórias em tempos neoliberais (pp. 13-29). Araraquara, Brazil: Junqueira \& Marin.

Cunha, M. I. (2007). O lugar da formação do professor universitário: a condição profissional em questão. In M. I. Cunha (Ed.), Reflexões e práticas em pedagogia universitária (pp. 11-25). Campinas, Brazil: Papirus.

Cunha, M. I. (2010). Trajetórias e lugares de formação da docência universitária: da perspectiva individual ao espaço institucional. Araraquara, Brazil: Junqueira \& Marin.

Cunha, M. I. (2014). Estratégias institucionais para o desenvolvimento profissional docente e as assessorias pedagógicas universitárias: memórias, experiências, desafios e possibilidades. Araraquara, Brazil: Junqueira \& Marin.

Imbernón, F. (2009). Formação permanente do professorado: novas tendências. São Paulo, Brazil: Cortez.

Imbernón, F. (2010). Formação continuada de professores. Porto Alegre, Brazil: Artmed.

Marcelo, C., \& Vaillant, D. (2009). Desarrollo profesional docente. Como se aprende a enseñar? Madrid, Espanha: Narcea.

Nóvoa, A. (1997). Formação de professores e profissão docente. In A. Nóvoa (Ed.), Os professores e a sua formação (pp. 9-33). Lisboa, Portugal: Dom Quixote.

Pachane, G. G. (2005). Teoria e prática na formação pedagógica do professor universitário: elementos para discussão. Publicatio UEPG: Ciências Humanas, Linguistica, Letras e Artes, 13(1), 13-24. http://dx.doi.org/10.5212/publ.humanas.v13i1.531

Pimenta, S. G. (2009). A profissão professor universitário: processos de construção da identidade docente. In M. I. Cunha, S. R. Soares, \& M. L. Ribeiro (Eds.), Docência universitária: profissionalização e práticas educativas (pp. 33-55). Feira de Santana, Brazil: UEFS.

Pimenta, S. G., \& Anastasiou, L. G. C. (2014). Docência no ensino superior. São Paulo, Brazil: Cortez.

Severino, A. J. (2002). Educação e universidade: conhecimento e construção da cidadania. Interface (Botucatu), 
6(10), 117-124. http://dx.doi.org/10.1590/S1414-32832002000100015

Sobrinho, J. D. (2005). Educação superior, globalização e democratização: qual universidade? Revista Brasileira de Educação, 28, 164-173. http://dx.doi.org/10.1590/S1413-24782005000100014

Universidade de São Paulo. (2004). Portaria Interna Pró-G no 04/2004: Dispõe sobre as principais ações de apoio pedagógico ao docente na Universidade de São Paulo. São Paulo, Brazil: USP.

Zabalza, M. A. (2004). O ensino universitário: seu cenário e seus protagonistas. Porto Alegre, Brazil: Artmed.

\section{Copyrights}

Copyright for this article is retained by the author(s), with first publication rights granted to the journal.

This is an open-access article distributed under the terms and conditions of the Creative Commons Attribution license (http://creativecommons.org/licenses/by/4.0/). 